\title{
Biological Control of Crown Gall of Grapevine, Rose, and Tomato by Nonpathogenic Agrobacterium vitis Strain VAR03-1
}

\author{
A. Kawaguchi, K. Inoue, and Y. Ichinose
}

First and second authors: Laboratory of Plant Pathology and Entomology, Agricultural Experiment Station, Okayama Prefectural General Agriculture Center, 1174-1 Koda-Oki, Akaiwa, Okayama 709-0801, Japan; and third author: The Graduate School of Natural Science and Technology, Okayama University, 1-1-1 Tsushima-naka, Okayama 700-8530, Japan.

Accepted for publication 2 July 2008.

\section{ABSTRACT}

Kawaguchi, A., Inoue, K., and Ichinose, Y. 2008. Biological control of crown gall of grapevine, rose, and tomato by nonpathogenic Agrobacterium vitis strain VAR03-1. Phytopathology 98:1218-1225.

A nonpathogenic strain of Agrobacterium vitis VAR03-1 was tested as a biological control agent for crown gall of grapevine (Vitis vinifera). When roots of grapevine, rose (Rose multiflora), and tomato (Lycopersicon esculentum) were soaked in a cell suspension of antagonists before planting in soil infested with tumorigenic $A$. vitis, $A$. rhizogenes, and $A$. tumefaciens, respectively, treatment with VAR03-1 significantly reduced the number of plants with tumors and disease severity in the three plant species. The inhibitory effects of treatment with VAR03-1 and the nonpathogenic A. rhizogenes strain K84 on crown gall of rose and tomato were almost identical, and the inhibitory effect of VAR03-1 on grapevine was superior to that of K84. Moreover, VAR03-1 greatly controlled crown gall of grapevine due to tumorigenic $A$. vitis in the field. VAR03-1 established populations averaging $10^{6}$ colony forming units $(\mathrm{CFU}) / \mathrm{g}$ of root in the rhizosphere of grapevine and persisted on roots for 2 years. VAR03-1 was bacteriocinogenic, producing a halo of inhibition against those three species of Agrobacterium. This is the first report that a nonpathogenic strain, VAR03-1, can effectively control crown gall caused by tumorigenic A. vitis, A. rhizogenes, and A. tumefaciens.
Grapevine crown gall due to Agrobacterium vitis Ophel and Kerr 1990 (=Agrobacterium tumefaciens biovar 3 [Smith and Townsend 1907] Conn 1942, Rhizobium vitis Young et al. 2001 ) is the most important bacterial disease of grapevine throughout the world (3,6,31). The nonpathogenic Agrobacterium rhizogenes (Riker, Banfield, Wright, Keitt, and Sagen, 1930) Conn 1942 (=Agrobacterium radiobacter biovar 2 [Beijerinck and van Delden 1902] Conn 1942, Rhizobium rhizogenes Young et al. 2001) strain K84 has been used successfully to control crown gall in many plant species $(24,27)$. An agrocin produced by K84 (agrocin 84 ), which is thought to be the primary factor in the control (14), targets a tRNA synthetase in the tumorigenic Agrobacterium strains (28). Recombinant DNA techniques have been used to construct a new biological control strain, K1026, that is identical to K84 apart from 5.9-kb deletion overlapping the Tra region of pAgK84 (13). K1026 is unable to transfer its mutant agrocin 84 plasmid, designated pAgK1026, to other agrobacteria, but remains inhibitory to strains sensitive to agrocin $84(13,26)$. However, K84 does not prevent the initial infection of grapevine by tumorigenic $A$. vitis $(3,4,16,17)$.

Several laboratories have attempted to identify other biological control agents for grapevine crown gall $(5,7,8,32,36$, 37). Staphorst et al. (32) evaluated 16 strains, including the nonpathogenic $A$. vitis strain $\mathrm{F} 2 / 5$, that inhibited growth of most tumorigenic strains of $A$. vitis in vitro and inhibited crown gall on grapevine in stem-wounding experiments in the greenhouse. Burr and Reid (5) reported that F2/5 produced a

Corresponding author: A. Kawaguchi

E-mail address: akira_kawaguchi@pref.okayama.lg.jp

doi:10.1094/PHYTO-98-11-1218

(C) 2008 The American Phytopathological Society bacteriocin and effectively inhibited tumor formation at wound sites on grapevine stems inoculated with one of the tumorigenic $A$. vitis strains. However, F2/5 had very low antibiotic activity against tumorigenic $A$. tumefaciens (=A. tumefaciens biovar 1$)$ and $A$. rhizogenes $(=A$. tumefaciens biovar 2$)$ (5) and did not inhibit tumor formation caused by other strains of tumorigenic A. vitis (7). Wang et al. (36) reported that an antibacterial compound named "Ar26" produced by nonpathogenic A. vitis strain E26 inhibited the growth of tumorigenic A. vitis strain MI3-2 and A. tumefaciens strain CY4 on culture plates.

Previously, we reported that a nonpathogenic A. vitis strain, VAR03-1, isolated from nursery stock of grapevine in Japan produced a bacteriocin and greatly inhibited tumor formation on the stems of tomato and grapevine seedlings caused by several tumorigenic $A$. vitis strains isolated from different grapevine fields in Japan $(16,17)$. In greenhouse tests, when roots of grapevine seedlings were soaked in a cell suspension of strain VAR03-1 for $24 \mathrm{~h}$ before a 1-h soak in a cell suspension of tumorigenic $A$. vitis and subsequent planting in pots of infested soil, strain VAR03-1 significantly reduced the incidence of tumor formation (17).

Today, crown gall diseases on rose and grapevine occur in many countries around the world $(3,23)$. Rose crown gall is caused by mainly tumorigenic A. rhizogenes in Japan (23). Further, tomato crown gall caused by tumorigenic $A$. tumefaciens was recognized in the United Kingdom in 2005 (38), indicating the possibility that tomato crown gall will be found in other countries. In the present paper, we report that soaking the roots in cells suspensions of strain VAR03-1 reduced the frequency of crown gall of grapevine, rose, and tomato caused by several tumorigenic strains of A. vitis, A. rhizogenes, and A. tumefaciens, respectively, in the greenhouse test and controlled crown gall of grapevine by several tumorigenic A. vitis strains in the field. 
We follow the nomenclature for Agrobacterium species adopted in Bergey's Manual of Systematic Bacteriology (40) and as reported by Ophel and Kerr (25) to avoid confusion, although other valid naming systems have been proposed $(1,11,20,30,39)$.

\section{MATERIALS AND METHODS}

Biological control in greenhouse experiment. Biological control assays based on the method we established (17) were carried out using seedlings and nursery stocks. Seedlings of tomato (Lycopersicon esculentum Mill. cv. Ponderosa) (1 to 2 months old) and grapevine (Vitis vinifera L. cv. Neo Muscat) (1 year old) were grown from seeds using methods previously reported (9). Nursery stocks of rose (scion cultivar: Rose hybrida L. cv. Rote Rose, rootstock: Rose multiflora Thunb. cv. Multiflora Rose) grown from cuttings for 1 year were prepared.

Cell suspensions of nonpathogenic strains VAR03-1 and K84 were prepared from 48-h slant cultures grown on potato semi-synthetic agar (PSA) medium $(300 \mathrm{~g}$ of potato, $0.5 \mathrm{~g}$ of $\mathrm{Ca}\left(\mathrm{NO}_{3}\right)_{2} 4 \mathrm{H}_{2} \mathrm{O}, 2 \mathrm{~g}$ of $\mathrm{Na}_{2} \mathrm{HPO}_{4} 12 \mathrm{H}_{2} \mathrm{O}, 5 \mathrm{~g}$ of peptone, $20 \mathrm{~g}$ of sucrose, $15 \mathrm{~g}$ of agar, and 1 liter of distilled water, $\mathrm{pH} 6.8$ to 7.0) and adjusted to $\mathrm{OD}_{600}=1.0$ (corresponding to about $10^{9}$ cells $\left./ \mathrm{ml}\right)$ for inoculation, and 10 tumorigenic strains $(A$. tumefaciens strains $\mathrm{CH} 3, \mathrm{CH} 5$, and $\mathrm{C} 054 ; A$. rhizogenes strains AtR1, Ch-Ag-2, and P-Ag-1; A. vitis strains At-90-23, G-Ag-27, MAFF211674, and MAFF211676) (Table 1) that were adjusted to about $10^{8}$ cells $/ \mathrm{ml}\left(\mathrm{OD}_{600}=0.1\right)$. The soil was inoculated with each Agrobacterium pathogen by pouring $10^{8}$ cells $/ \mathrm{ml}$ cell suspensions onto the soil $(500 \mathrm{ml} / \mathrm{kg}$ of soil $)$ and to obtain a final concentration about $5 \times 10^{7}$ cells $/ g$ of soil. Each young plant was pulled from the soil and the root rinsed in water until clean. Roots were then pruned and soaked for $1 \mathrm{~h}$ in a cell suspension of strain VAR03-1, K84, or sterile distilled water (as a control) at $25^{\circ} \mathrm{C}$. After soaking, 15 tomato seedlings per treatment were planted in pots $(10 \mathrm{~cm}$ depth $\times 12 \mathrm{~cm}$ diameter, one plant per pot) with soil infested with a mixture of three tumorigenic $A$. tumefaciens strains at a final concentration $5 \times 10^{7}$ cells $/ g$ of soil in soil $8 \mathrm{~cm}$ deep. Correspondingly, 15 rose nursery stocks were planted in pots $(12 \mathrm{~cm}$ depth $\times 15 \mathrm{~cm}$ diameter) with soil infested with a mixture of cell suspension of three tumorigenic A. rhizogenes strains at a final concentration of $10^{8}$ cells/g of soil in soil $10 \mathrm{~cm}$ deep, and 15 grapevine seedlings were planted in pots (12 cm depth $\times 15 \mathrm{~cm}$ diameter) with soil infested with a mixture of four tumorigenic A. vitis strains at a final concentration $5 \times 10^{7}$ cells $/ g$ of soil in soil $10 \mathrm{~cm}$ deep. Plants were then grown in a temperature-controlled greenhouse at 25 to $28^{\circ} \mathrm{C}$, and tumor formation was assessed after 2 months for tomato, 5 months for rose, and 3 months for grapevine. The tomato and rose experiment were repeated three times, and the grapevine experiment was repeated four times.

Protective value was defined in terms of previous report by Penyalver and López (26) as follows: Protective value = $100 \%-([\%$ of plants with tumors in treatment $\times 100] /[\%$ of plants with tumors in sterile distilled water treatment]).

Biological control in field experiment. In 2007, two experiments on biological control for grapevine crown gall were carried out in the field at the experimental farm of the Okayama Prefectural General Agriculture Center in Akaiwa City, Okayama, Japan.

In experiment 1 , the field trial was conducted using concrete-frame plots $(1.5 \mathrm{~m} \times 1.6 \mathrm{~m} / \mathrm{plot}, 1.0 \mathrm{~m}$ tall $)$ filled in the soil $\left(\mathrm{pH}=6.0, \mathrm{NO}_{3}-\mathrm{N}=7.2 \mathrm{mg} / 100 \mathrm{~g}\right.$ of soil, $\mathrm{P}_{2} \mathrm{O}_{5}=119$ $\mathrm{mg} / 100 \mathrm{~g}$ of soil, $\mathrm{K}_{2} \mathrm{O}=67 \mathrm{mg} / 100 \mathrm{~g}$ of soil, $\mathrm{CaO}=255 \mathrm{mg} /$ $100 \mathrm{~g}$ of soil, the cation exchange capacity $=14.2 \mathrm{meq} / 100 \mathrm{~g}$ of soil, organic matter content $=1.7 \%$ ). One month before the experiment, a commercial organic fertilizer (Temporon, including ligno-cellulose, humic acid, $\mathrm{Ca}, \mathrm{Mg}, \mathrm{Mn}$, and $\mathrm{B}$; Mitsubishi-Shouji, Tokyo, Japan) was applied at a rate of $4.5-\mathrm{kg}$ per plot and thoroughly incorporated. Two weeks before the experiment, 20 liters per plot of a mixed cell suspension (about $10^{8}$ cells $/ \mathrm{ml}$ ) of tumorigenic A. vitis strains At-9023, G-Ag-27, MAFF211674, and MAFF211676 was poured on. Cell suspensions of nonpathogenic strains VAR03-1 and K84 were adjusted to about $10^{9}$ cells $/ \mathrm{ml}$, respectively. The roots of grapevine seedlings cv. Neo Muscat (1 year old) were pruned and soaked for $1 \mathrm{~h}$ in a cell suspension of strain VAR03-1, K84, or sterile distilled water at $25^{\circ} \mathrm{C}$ in each treatment and then these 14 grapevine seedlings per treatment were planted in the center area of each plot in six rows (two rows per treatment; VAR03-1, K84, and sterile distilled water, respectively) spaced $15 \mathrm{~cm}$ apart with a $15 \mathrm{~cm}$ space between

TABLE 1. Bacterial strains used in this study

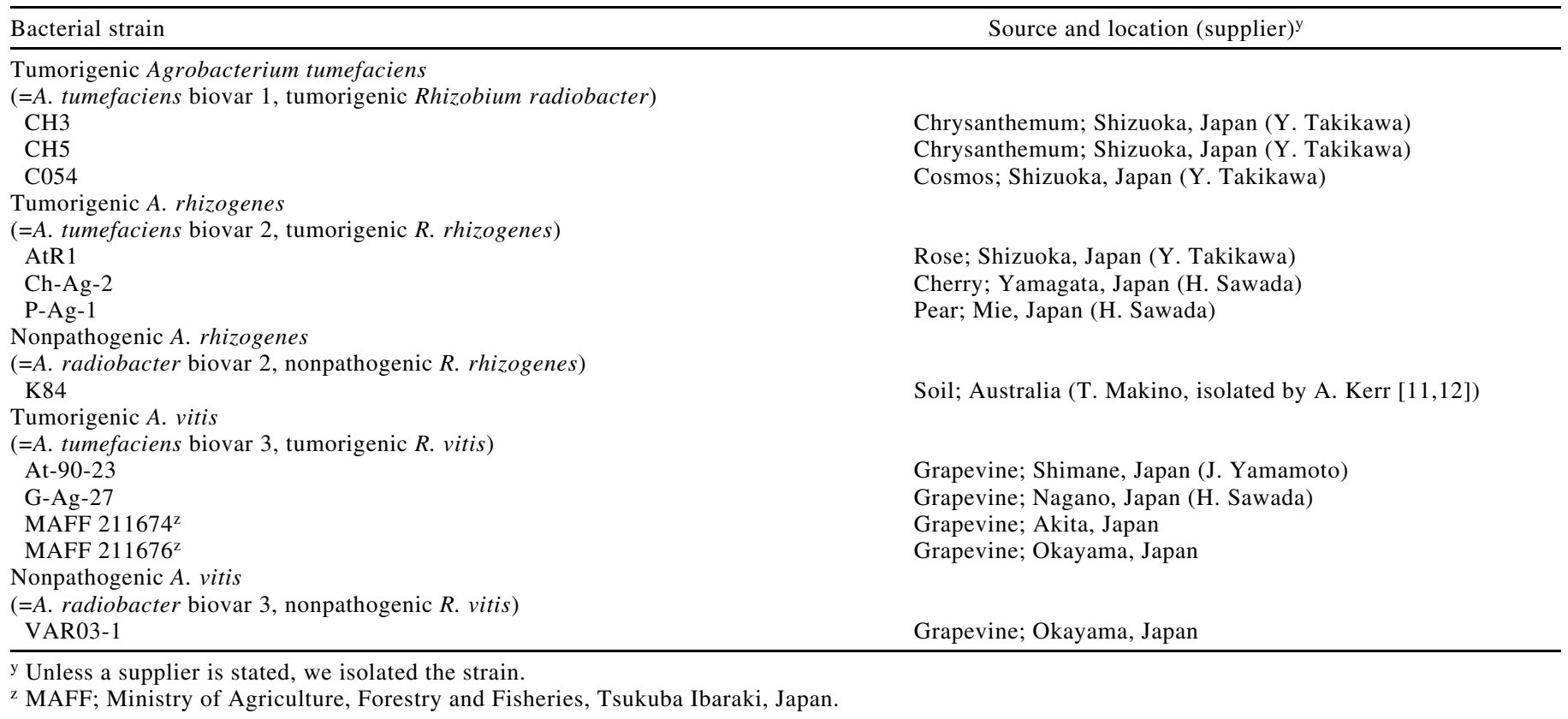


each plant on 13 February 2007. The topsoil in each concreteframe plot was covered by a sheet of nonwoven fabric as covering material to weed after planting. Tumor formation was investigated on 12 October 2007. Three plots were used for this experiment.

In experiment 2 , the field trial was carried out using grapevine nursery stocks $V$. vinifera $\times V$. labrusca cv. Pione grown from cuttings ( 2 years old). The field experiment was conducted using nonframe plots $(8.0 \mathrm{~m} \times 3.0 \mathrm{~m} / \mathrm{plot})$. One month before the experiment, the commercial organic fertilizer described previously was applied at a rate of $45 \mathrm{~kg}$ per plot and thoroughly incorporated. Two weeks before the experiment, 90 liters of a mixed cell suspension (about $5 \times 10^{7}$ cells/ ml) of tumorigenic A. vitis strains At-90-23, G-Ag-27, MAFF211674, and MAFF211676 per plot was poured on, and then soil was broken up in depth $16 \mathrm{~cm}$ by the cultivator Punch-X F402-J (Honda Motor, Tokyo, Japan) to disperse the inoculum. Cell suspensions of nonpathogenic strain VAR03-1 were adjusted to about $10^{9}$ cells $/ \mathrm{ml}$. Fifteen grapevine nursery stocks per treatment were inoculated as described previously and planted in the center area of each plot in two rows (one row per treatment; VAR03-1 and sterile distilled water, respectively) spaced $150 \mathrm{~cm}$ apart with a $50 \mathrm{~cm}$ spacing between plants on 19 April 2007. The ground in each plot was covered by a sheet of nonwoven fabric as covering material to weed after planting. Tumor formation was investigated on $27 \mathrm{No}$ vember 2007. Three plots were used in this experiment.

The rainy season in Okayama, Japan, was from June to July. The temperature ranged from 10 to $37^{\circ} \mathrm{C}$, and no severe damage by weather or insects was observed during the cultivation. The severity of crown gall disease was assayed as described previously for the greenhouse experiment.

In vitro antibiosis assay. The antibiosis assay, based on previous reports (16), consisted of placing a sterile paper disk (8-mm diameter) with a $50-\mu l$ drop of the test strain (about $10^{8}$ cells $\left./ \mathrm{ml}\right)$ on yeast-mannitol agar (YMA) medium $(0.4 \mathrm{~g}$ of yeast extract, $10 \mathrm{~g}$ of mannitol, $0.1 \mathrm{~g}$ of $\mathrm{NaCl}, 0.2 \mathrm{~g}$ of $\mathrm{MgSO}_{4}, 0.5 \mathrm{~g}$ of $\mathrm{K}_{2} \mathrm{HPO}_{4}, 15 \mathrm{~g}$ of agar, and 1 liter of distilled water, $\mathrm{pH} 7.0$ ), and incubating it for 2 days at $27^{\circ} \mathrm{C}$. Each test strain was spotted onto four plates. After the test strains K84 and VAR03-1 were killed with chloroform on each plate, the plates were misted with a dilute suspension of Agrobacterium strains (A. tumefaciens strains $\mathrm{CH} 3, \mathrm{CH} 5$, and $\mathrm{C} 054$; A. rhizogenes strains AtR1, Ch-Ag-2, and P-Ag-1; A. vitis strains At90-23, G-Ag-27, MAFF211674, and MAFF211676) (Table 1) as an indicator (sensitive) strain. The plates were photgraphed 2 days after misting, and the diameter of the halo of inhibition indicative of antibiosis, was measured.

Survival assay. The survival rate of nonpathogenic A. vitis strain VAR03-1 and A. rhizogenes strain K84 in the grapevine seedling root was determined. Thirty seedlings of grapevine cv. Neo Muscat grown for 1 year were prepared. Cell suspensions of nonpathogenic strain VAR03-1 and K84 contained $10^{8}$ cells/ml, respectively. Grapevine seedlings were root inoculated as described for the biological control in the greenhouse experiment: grapevine seedlings were soaked for $24 \mathrm{~h}$ in a cell suspension $\left(10^{8}\right.$ cells $\left./ \mathrm{ml}\right)$ or for $1 \mathrm{~h}$ in a cell suspension $\left(10^{9}\right.$ cells $\left./ \mathrm{ml}\right)$, and planted in pots $(12 \mathrm{~cm}$ depth $\times 15 \mathrm{~cm} \mathrm{di}-$ ameter) with soil. Nontreatment grapevine seedlings with the test strain were prepared as negative control. The temperature ranged from 20 to $30^{\circ} \mathrm{C}$. To determine the populations of each strain, roots (1 $\mathrm{g}$ of fresh weight per plant) were collected from 3 or 10 randomly selected plants. Each piece was scrubbed and rinsed under tap water and dried with paper towels. To avoid an influence of the nonhomogeneous colonization by the other bacteria in the roots, the surface was treated with $70 \%$ ethanol for $1 \mathrm{~min}$ and washed with sterile distilled water, and then mashed with an autoclaved mortar and pestle in $1 \mathrm{ml}$ of sterile distilled water. Serial dilutions of grapevine treated with VAR03-1 were plated on 3DG medium, which is selective for $A$. vitis (2), and serial dilutions of grapevine treated with $\mathrm{K} 84$ were plated on $2 \mathrm{E}$ medium for $A$. rhizogenes (2). The plates were incubated at $28^{\circ} \mathrm{C}$ for 5 days. The observations were based on three plates of each dilution, and colony forming units (CFU) of A. vitis and A. rhizogenes were counted on each selective medium. The bacterial population on the root was transformed as a logarithm (base 10) of CFUs per gram of root for analysis. Characteristic colonies of A. vitis on $3 \mathrm{DG}$ medium and $A$. rhizogenes on $2 \mathrm{E}$ medium were counted, but similar colonies on $3 \mathrm{DG}$ were determined by a colony-direct multiplex polymerase chain reaction (PCR) method for diagnosis of $A$. vitis (19). After multiplex PCR, a total of 10 to $20 \mathrm{~A}$. vitis colonies per plate were isolated and analyzed. The rep-PCR DNA fingerprint analysis with BOX and ERIC primer sets (18) was performed to confirm that the isolates from these colonies showed the same fingerprint pattern of strain VAR03-1. Furthermore, the antibiosis activity of the isolates were confirmed against G-Ag-27 as an indicator strain described previously. As for strain K84 on $2 \mathrm{E}$ medium, a total of 10 to 20 A. rhizogenes colonies per plate were isolated and analyzed agrocin 84 production according to the Stonier procedure $(21,34,35)$ to confirm strain K84.

Data analysis. In this study, statistical analyses were performed using the software STATISTICA 03J (StatSoft Inc., Tulsa, OK). The data on plants with tumors (\%) and disease severity in the greenhouse experiments and field experiment 1 were subjected to analysis of variance (ANOVA), and the mean values in each treatment were compared with Fisher's protected least significant difference (LSD) test at $P=0.05$. The data on greenhouse experiments were pooled and analyzed. In field experiment 2, Student's $t$ test was used to compare the number of plants with tumors treated with strain VAR03-1 to those treated with sterile distilled water. Differences between the radius of the halo of inhibition against each tumorigenic Agrobacterium strain of VAR03-1 and K84 were compared using the Mann-Whitney $U$-test. The data on root colonization of strain VAR03-1 and K84 in the roots of grapevine were subjected to ANOVA, and the mean values in each treatment were compared with Scheffe's test.

\section{RESULTS}

Biological control in greenhouse experiment. The biological control assays in the greenhouse using the method of soaking the roots in a cell suspension of the antagonist were performed before planting grapevine, tomato seedlings, and rose nursery stocks in soil infested with tumorigenic strains of A. vitis, A. tumefaciens, and A. rhizogenes. Tumors formed on plants in these experiments were observed on roots and on a stem. Treatment of tomato roots with nonpathogenic $A$. vitis strain VAR03-1 or A. rhizogenes strain K84 significantly reduced the percentage of tomato seedlings with tumors caused by the three tumorigenic $A$. tumefaciens strains $(P<0.05)$; the protective values of VAR03-1 and K84 against crown gall of tomato were 63.6 and $69.7 \%$, respectively (Table 2). VAR03-1 or K84 treatment of rose roots significantly reduced the percentage of plants with tumors caused by the three tumorigenic A. rhizogenes strains $(P<0.05)$, and the protective values of VAR03-1 and K84 against crown gall of rose were 73.0 and $82.2 \%$, respectively (Table 2). Moreover, VAR03-1 treatment of grapevine roots also significantly reduced the percentage of plants with tumors caused by four tumorigenic $A$. vitis strains $(P<0.05)$; the protective value of VAR03-1 against crown gall of grapevine was $91.8 \%$, although K84 treatment of grapevine roots scarcely inhibited the outbreak of crown gall disease because the protective value of K84 was $12.0 \%$ (Table 2). 
Biological control in field experiment. Biological control assays using the method of planting grapevine seedlings cv. Neo Muscat and nursery stocks cv. Pione were performed in the field in 2007. The grapevine was infested in the soil with four tumorigenic $A$. vitis strains isolated from different fields in Japan (Table 1). In experiment 1, as shown in Table 3, VAR03-1 treatment of grapevine roots inhibited crown gall of grapevine completely $(P<0.05)$, and thus the protective value of VAR03-1 was $100 \%$. On the other hand, K84 treatment of grapevine roots hardly reduced the percentage of plants with tumors, and the result was not significantly different from that of the treatment with sterile distilled water as the control. In experiment 2, treatment of grapevine roots with strain
VAR03-1 significantly reduced the percentage of plants with tumors $(P<0.05)$, and the protective value against crown gall of grapevine was $92.4 \%$ (Table 3 ).

In vitro antibiosis assay. Nonpathogenic Agrobacterium strains VAR03-1 and K84 were used as test strains for an in vitro antibiosis assay against various strains of three species of tumorigenic Agrobacterium. Some combinations of test and indicator strains resulted in halos of inhibition on YMA medium (Fig. 1 and Table 4). In addition, VAR03-1 inhibited all indicator strains including three species of agrobacteria (10 of 10 strain combinations), and the inhibition halo of VAR03-1 was significantly wider than that of K84 against eight indicator strains $(P<0.05)$. K84 did not inhibit tumorigenic

TABLE 2. Effect of nonpathogenic Agrobacterium strains VAR03-1 and K84 on crown gall of tomato and rose after soaking plant roots in bacterial cell suspensions in the greenhouse experiments

\begin{tabular}{|c|c|c|c|c|c|c|c|}
\hline \multirow[b]{2}{*}{ Treatment } & \multirow[b]{2}{*}{$\begin{array}{c}\text { No. of } \\
\text { experiment }\end{array}$} & \multicolumn{2}{|c|}{ Tomato $^{\mathrm{v}}$} & \multicolumn{2}{|c|}{ Rose $^{w}$} & \multicolumn{2}{|c|}{ Grapevine $^{\mathrm{x}}$} \\
\hline & & $\begin{array}{l}\text { Plants with } \\
\text { tumors }(\%)^{\mathrm{y}}\end{array}$ & $\begin{array}{l}\text { Protective value } \\
(\%)^{\mathrm{z}}\end{array}$ & $\begin{array}{l}\text { Plants with } \\
\text { tumors (\%) }\end{array}$ & $\begin{array}{c}\text { Protective value } \\
(\%)\end{array}$ & $\begin{array}{l}\text { Plants with } \\
\text { tumors }(\%)\end{array}$ & $\begin{array}{c}\text { Protective value } \\
(\%)\end{array}$ \\
\hline \multirow[t]{4}{*}{ VAR03-1 } & 1 & 20.0 & & 10.0 & & 6.7 & \\
\hline & 3 & 33.3 & & 5.0 & & 0.0 & \\
\hline & 4 & NT & & NT & & 6.7 & \\
\hline & Mean & $26.7 \mathrm{a}$ & 63.6 & $5.0 \mathrm{a}$ & 73.0 & $3.4 \mathrm{a}$ & 91.8 \\
\hline \multirow{3}{*}{ K84 } & 3 & 6.7 & & 0.0 & & 13.3 & \\
\hline & 4 & NT & & NT & & 46.7 & \\
\hline & Mean & $22.2 \mathrm{a}$ & 69.7 & $3.3 \mathrm{a}$ & 82.2 & $36.7 \mathrm{~b}$ & 12.0 \\
\hline \multirow{4}{*}{ Sterile distilled water } & 1 & 40.0 & & 20.0 & & 53.3 & \\
\hline & 2 & 80.0 & & 25.0 & & 40.0 & \\
\hline & 3 & 100.0 & & 10.0 & & 33.3 & \\
\hline & 4 & NT & & NT & & 40.0 & \\
\hline
\end{tabular}

${ }^{\mathrm{v}}$ Data are means of three experiments of 15 tomato seedlings per treatment. Plants were soaked in cell suspension of antagonist ( $10^{9}$ cells/ml) or sterile distilled water $1 \mathrm{~h}$ before being planted in a pot in soil infected with the mixture of cell suspension of tumorigenic A. tumefaciens strain $\mathrm{CH} 3$, $\mathrm{CH} 5$, and $\mathrm{C} 054$ at a final concentration $5 \times 10^{7}$ cells/g of soil.

${ }^{\mathrm{w}}$ Data are means of three experiments of 20 rose nursery stocks per treatment. Plants were soaked in cell suspension of antagonist $\left(10^{9}\right.$ cells $\left./ \mathrm{ml}\right)$ or sterile distilled water $1 \mathrm{~h}$ before being planted in a pot in soil infected with the mixture of cell suspension of tumorigenic A. rhizogenes strain AtR1, $\mathrm{Ch}-\mathrm{Ag}-2$, and P-Ag-1 at a final concentration $5 \times 10^{7}$ cells $/ \mathrm{g}$ of soil.

${ }^{x}$ Data are means of four experiments of 15 grapevine seedlings per treatment. Plants were soaked in cell suspension of antagonist $\left(10^{9}\right.$ cells $\left./ \mathrm{ml}\right)$ or sterile distilled water $1 \mathrm{~h}$ before being planted in a pot in soil infected with the mixture of cell suspension of tumorigenic A. vitis strain At-90-23, GAg-27, MAFF 211674 , and MAFF 211676 at a final concentration $5 \times 10^{7}$ cells $/ g$ of soil.

y Means followed by the same letter are not significantly different according to Fisher's protected least significant difference test on the arcsine transformation of the data at $P<0.05$. NT; not tested.

${ }^{\mathrm{z}}$ Protective value $=100 \%-([\%$ of plants with tumors in treatment $\times 100] /[\%$ of plants with tumors in sterile distilled water treatment $])$.

TABLE 3. Effect of nonpathogenic Agrobacterium strains VAR03-1 and K84 on crown gall of grapevine seedlings after soaking plant roots in bacterial cell suspensions ${ }^{\mathrm{w}}$

\begin{tabular}{|c|c|c|c|c|c|}
\hline \multirow[b]{2}{*}{ Treatment } & \multirow[b]{2}{*}{ No. of replication } & \multicolumn{2}{|c|}{ Experiment 1} & \multicolumn{2}{|c|}{ Experiment 2} \\
\hline & & Plants with tumors $(\%)^{\mathrm{x}}$ & Protective value $(\%)^{\mathrm{y}}$ & Plants with tumors $(\%)^{\mathrm{z}}$ & Protective value $(\%)$ \\
\hline \multirow[t]{3}{*}{ VAR03-1 } & 1 & 0.0 & & 6.7 & \\
\hline & 2 & 0.0 & & 0.0 & \\
\hline & Mean & $0.0 \mathrm{a}$ & 100.0 & $2.2 *$ & 92.4 \\
\hline \multirow[t]{2}{*}{ K84 } & 1 & 21.4 & & NT & \\
\hline & 2 & 7.1 & & NT & \\
\hline \multirow{3}{*}{ Sterile distilled water } & 2 & 14.3 & & 20.0 & \\
\hline & 3 & 7.7 & & 20.0 & \\
\hline & Mean & $14.0 \mathrm{~b}$ & $\ldots$ & 28.9 & $\ldots$ \\
\hline
\end{tabular}

${ }^{\mathrm{w}}$ Data are means of three replications of 14 grapevine seedlings per treatment in experiment 1 and three replications of 15 grapevine nursery stocks per treatment in experiment 2. Plants were soaked in a cell suspension of antagonist $\left(10^{9} \mathrm{cells} / \mathrm{ml}\right)$ or sterile distilled water $1 \mathrm{~h}$ before being planted in the field. NT; not tested.

${ }^{x}$ Means followed by the same letter are not significantly different according to Fisher's protected least significant difference test on the arcsine transformation of the data at $P<0.05$.

${ }^{\mathrm{y}}$ Protective value $=100 \%-([\%$ of plants with tumors in treatment $\times 100] /[\%$ of plants with tumors in sterile distilled water treatment $])$.

z Significantly different according to Student's $t$ test on the arcsine transformation of the data at $P<0.05$. 
A. tumefaciens C054 or any of tumorigenic A. vitis strains examined in this study (Table 4).

Population dynamics of strain VAR03-1 and K84 on root of grapevine. One month after grapevine roots were pruned and soaked for $24 \mathrm{~h}$ in a cell suspension of nonpathogenic $A$. vitis strain VAR03-1 $\left(10^{8}\right.$ cells $\left./ \mathrm{ml}\right)$, the bacterial population was about $10^{7} \mathrm{CFU} / \mathrm{g}$ (fresh weight) of grapevine root (Table 5). Colonization of VAR03-1 remained at $10^{6}$ to $10^{7} \mathrm{CFU} / \mathrm{g}$ of root for up to 7 to 14 months, then dropped to about $10^{4}$ to $10^{5} \mathrm{CFU} / \mathrm{g}$ of root after 22 months (Table 5). VAR03-1 established populations averaging $10^{6} \mathrm{CFU} / \mathrm{g}$ of root in the rhizosphere of grapevine and persisted in roots for 2 years. The rep-PCR analysis confirmed the identity of the isolates as VAR03-1 (Fig. 2), and all isolates showed in vitro antibiosis activity as well as VAR03-1 (Fig. 3). In contrast, characteristic colonies of $A$. vitis on $3 \mathrm{DG}$ medium isolated from nontreatment plants with VAR03-1 were not formed (Table 5).

One month after grapevine roots were soaked for 1 and $24 \mathrm{~h}$ in a cell suspension of $10^{9}$ and $10^{8}$ cells/ml of VAR03-1 and $10^{9}$ and $10^{8}$ cells $/ \mathrm{ml}$ of $\mathrm{K} 84$, respectively, the bacterial popu-

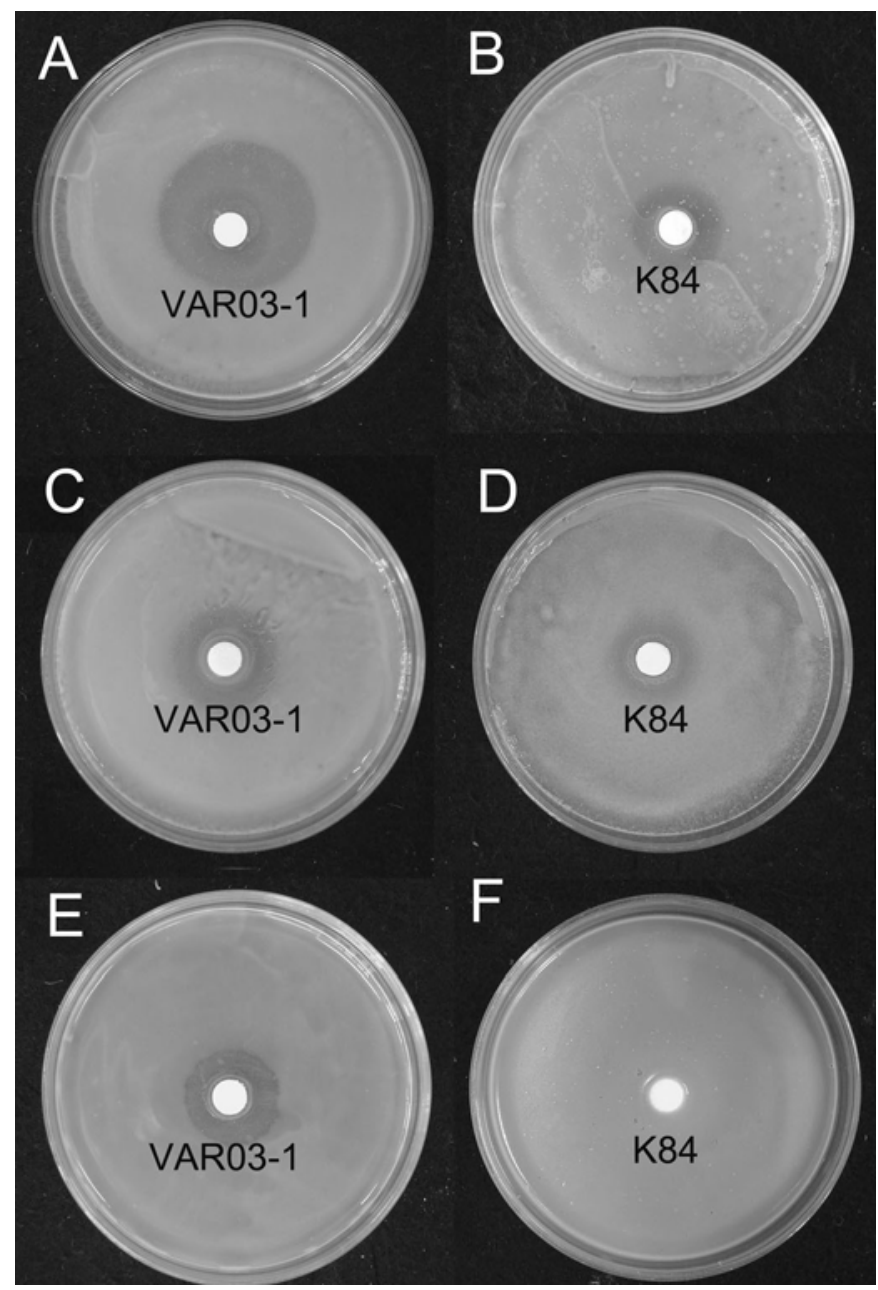

Fig. 1. In vitro antibiosis assay against tumorigenic Agrobacterium spp. Paper disks with a suspension of either nonpathogenic A. vitis strain VAR03-1 (A, C, and E) or nonpathogenic A. rhizogenes strain K84 (B, D, and F) were placed on yeast mannitol agar (YMA) medium plates, which were then misted with a dilute suspension of tumorigenic A. tumefaciens strain CH5 (A and B), tumorigenic A. rhizogenes strain Ch-Ag-2 (C and D), or tumorigenic A. vitis strain G-Ag-27 (E and F). Two days after misting, a halo of growth inhibition was seen around the paper disk with the suspension of VAR03-1 (A, C, and E) against each tumorigenic Agrobacterium spp. and of K84 (B and D) against both tumorigenic $A$. tumefaciens and $A$. rhizogenes, but not around the one with K84 (F) against tumorigenic $A$. vitis. lations with all treatments were about or over $10^{7} \mathrm{CFU} / \mathrm{g}$ of root. Three months after, those with treatments at $10^{9}$ and $10^{8}$ cells/ml of VAR03-1 were about $10^{7} \mathrm{CFU} / \mathrm{g}$ of root, whereas those with both treatments at $10^{9}$ and $10^{8}$ cells $/ \mathrm{ml}$ of K84 were about $10^{5} \mathrm{CFU} / \mathrm{g}$ of root. And the bacterial population treated with VAR03-1 was significantly higher than that treated with K84 $(P<0.05)$. Eighteen months after grapevine roots were soaked for $24 \mathrm{~h}$ in a cell suspension $\left(10^{8} \mathrm{cells} / \mathrm{ml}\right)$ of VAR03-1 and $\mathrm{K} 84$, though the bacterial population of VAR03-1 was about $10^{6} \mathrm{CFU} / \mathrm{g}$ of root, the population of K84 has already reached an undetectable level 18 months after application (Table 6).

\section{DISCUSSION}

The nonpathogenic $A$. vitis strain F2/5 has been studied as a biological control agent of grapevine crown gall and is effective against tumorigenic strains of A. vitis (5). However, the biological efficacy of F2/5 is specific to grapevine; F2/5 is not effective on other host plants such as tomato, sunflower, and devil's backbone (Kalanchoe daigremontiana) (7). In contrast, VAR03-1 seems to protect a wider variety of plant species than F2/5 does; VAR03-1 is effective not only on grapevine but also on tomato, rose (Table 2), and sunflower, as we have already reported (17). Moreover, VAR03-1 reduced the number of crown galls caused by several tumorigenic strains of $A$. vitis, A. rhizogenes, and A. tumefaciens when the plant roots were soaked in cell suspensions of VAR03-1 before planting in soil infested with pathogens (Table 2), indicating that VAR03-1 covers a wide range of host plants and tumorigenic Agrobacterium species. Strain K84, which can colonize numerous species of plants, is effective in controlling tumorigenic strains of A. tumefaciens and A. rhizogenes on peach, almond, raspberry, cherry, plum, rose, apple, euonymus, boysenberry, tomato, and chrysanthemum in greenhouse or field tests $(10,22,24)$. We will investigate further which species of plants VAR03-1 can colonize and control in field experiments.

In the two field experiments of biological control, soaking the roots of grapevine in a cell suspension of strain VAR03-1 before planting in soil infested with tumorigenic A. vitis significantly reduced the percentage of plants with tumors $(P<$ 0.05) (Table 3). The results obtained in the field experiment strongly indicated that soaking for $1 \mathrm{~h}$ in a $10^{9}$ cells $/ \mathrm{ml}$ of cell suspension of VAR03-1 is suitable for practical use. More

TABLE 4. In vitro antibiosis assay of nonpathogenic Agrobacterium strains against tumorigenic Agrobacterium strains

\begin{tabular}{lcc}
\hline & \multicolumn{2}{c}{$\begin{array}{c}\text { Formation of inhibition zone } \\
\text { on YMA medium }(\mathrm{mm})\end{array}$} \\
\cline { 2 - 3 } Indicator strain & K84 & VAR03-1 \\
\hline Tumorigenic A. tumefaciens & & \\
CH3 & $11.8 \pm 4.3$ & $19.6 \pm 0.7$ \\
CH5 & $6.1 \pm 3.5$ & $17.2 \pm 1.6^{*}$ \\
C054 & $0.0 \pm 0.0$ & $16.4 \pm 0.8^{*}$ \\
Tumorigenic A. rhizogenes & & \\
AtR1 & $5.3 \pm 1.3$ & $18.9 \pm 0.3$ \\
Ch-Ag-2 & $2.1 \pm 0.6$ & $20.0 \pm 1.9^{*}$ \\
P-Ag-1 & $1.5 \pm 0.1$ & $18.3 \pm 1.4^{*}$ \\
Tumorigenic A. vitis & & \\
At-90-23 & $0.0 \pm 0.0$ & $20.8 \pm 0.7^{*}$ \\
G-Ag-27 & $0.0 \pm 0.0$ & $21.7 \pm 2.8^{*}$ \\
MAFF 211674 & $0.0 \pm 0.0$ & $20.0 \pm 1.3^{*}$ \\
MAFF 211676 & $0.0 \pm 0.0$ & $14.8 \pm 0.3^{*}$ \\
\hline
\end{tabular}

${ }^{\mathrm{z}}$ Data are mean ( \pm standard error) radiuses of the inhibition zone of four replications per treatment. Strains with an inhibition zone wider than 1 $\mathrm{mm}$ were evaluated as sensitive. Means followed by an asterisk differ significantly $(P<0.05)$ between VAR03-1 and K84 according to the Mann-Whitney $U$ test on the square root transformation $(X+0.5)$ data. 
field experiments should be performed under different environmental conditions in the future to confirm the stability of the inhibitory effect.

Penyalver et al. (27) has suggested that the ability of strain K84 to colonize and persist on roots is important in the biological control process. Stockwell et al. (33) reported that K84 established populations averaging $10^{5} \mathrm{CFU} / \mathrm{g}$ (fresh weight) on galled root tissue in the rhizosphere of cherry after inoculation with a cell suspension $\left(10^{8} \mathrm{CFU} / \mathrm{ml}\right)$, but the populations dropped to about $10^{2} \mathrm{CFU} / \mathrm{g}$ of galled root tissue after 22 months. Our study demonstrated that a number of viable cells of K84 on grapevine roots after inoculation with $10^{8}$ or $10^{9}$ cells $/ \mathrm{ml}$ of cell suspensions were significantly smaller than that of VAR03-1 after 3 months and colonization of K84 has already been less than $10^{2} \mathrm{CFU} / \mathrm{g}$ of root after 18 months (Table 6). Furthermore, colonization of grapevine roots by VAR03-1 remained at $10^{4}$ to $10^{5} \mathrm{CFU} / \mathrm{g}$ of root after 22 months (Table 5) and that VAR03-1 established populations averaging $10^{6} \mathrm{CFU} / \mathrm{g}$ of root in the rhizosphere of grapevine, indicating that VAR03-1 persists on grapevine roots for up to 2 years. These results of comparison with survival of K84 and VAR031 on grapevine roots demonstrate that the ability of VAR03-1 to colonize and persist on grapevine roots is significantly superior to that of K84. Correspondingly, the ability of VAR03-1 to control grapevine crown gall was significantly superior to that of K84 in greenhouse and field experiments, and K84 could hardly control grapevine crown gall in greenhouse after 3 months and field experiments after 7 to 8 months (Tables 2 and 3). As Penyalver et al. (27) suggested, our results indicated that the population level of K84 on grapevine rhizosphere is important to control grapevine crown gall.

A number of viable cells of VAR03-1 on grapevine roots after soaking for 1 and $24 \mathrm{~h}$ in a cell suspension of $10^{9}$ and $10^{8}$ cells/ml of VAR03-1 were not significantly different but the efficiency of root colonization after treatment with $10^{9}$ cells $/ \mathrm{ml}$ seems to be better than that with $10^{8}$ cells $/ \mathrm{ml}$ after 1 and 3 months (Table 6). In the biological control test, the protective value of treatment with $10^{9}$ cells/ml of VAR03-1 soaking for $1 \mathrm{~h}$ against crown gall of grapevine was 91.8 to $100 \%$ in greenhouse and field experiments (Tables 2 and 3), but that of treatment with $10^{8}$ cells/ml of VAR03-1 for $24 \mathrm{~h}$ was $71.4 \%$ in greenhouse experiments that we had already reported (17). Thus, the abilities of VAR03-1 to colonize on grapevine roots treated with a cell suspension of $10^{9}$ cells $/ \mathrm{ml}$ of VAR03-1 for $1 \mathrm{~h}$ and to control crown gall were superior to that of treatment with $10^{8}$ cells $/ \mathrm{ml}$ for $24 \mathrm{~h}$, indicating the possibility that population level of VAR03-1 on grapevine rhizosphere have an effect on ability to control grapevine crown gall. Treatment condition of VAR03-1 with grapevine roots, which a cell suspension is $10^{9}$ cells $/ \mathrm{ml}$ and soaking time is $1 \mathrm{~h}$, is more suitable for practical use than a cell suspension of $10^{8}$ cells $/ \mathrm{ml}$ and soaking time for $24 \mathrm{~h}$ because short at soaking time, colonization ability on grapevine roots, and control ability of the former is better than those of latter.

The antibiotic production by strains VAR03-1 and K84 was indicated by a halo of inhibition in the bacterial lawn around the test strain (Fig. 2; Table 4). K84 produces an antibiotic named "agrocin 84" that selectively inhibits pathogenic agrobacteria (15), but $A$. vitis is insensitive to agrocin $84(3,4$, 14,16). In this study, it was confirmed that K84 did not inhibit tumorigenic A. vitis strains by production of agrocin 84 on YMA medium (Fig. 1; Table 4). Additionally, in vitro anti-
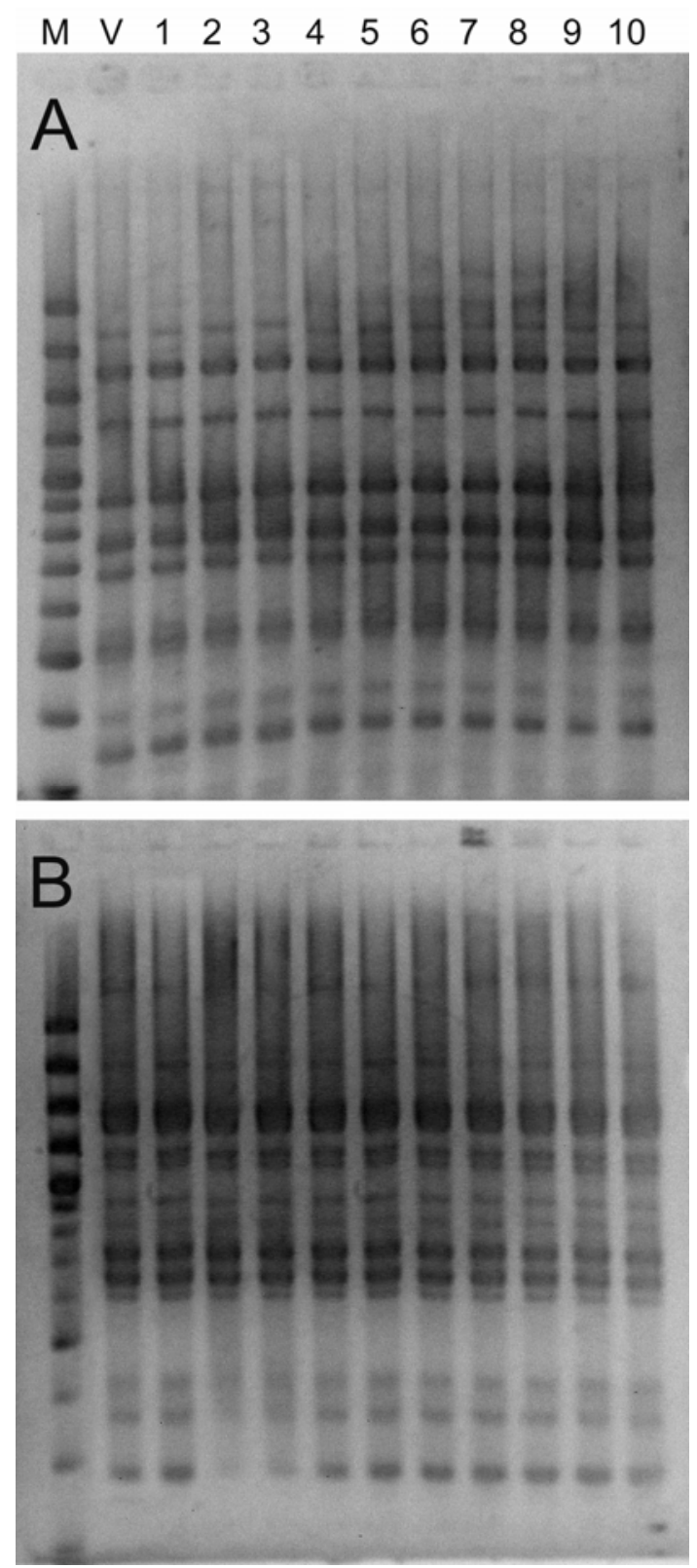

Fig. 2. DNA fingerprint patterns of 11 strains of Agrobacterium vitis revealed by rep-polymerase chain reaction DNA fingerprint analysis with BOX (A) and ERIC (B) primer sets. Lanes: M, 100-bp marker; V, VAR03-1; 1 to 10 , each isolate obtained from grapevine roots 18 months after treatment for $24 \mathrm{~h}$ in a cell suspension $\left(10^{8}\right.$ cells $\left./ \mathrm{ml}\right)$ of VAR03-1 in survival experiment of Table 6 .

TABLE 5. Population dynamics of nonpathogenic Agrobacterium vitis strain VAR03-1 in the roots of grapevine cv. Neo Muscat after inoculation

\begin{tabular}{|c|c|c|c|c|c|}
\hline \multirow[b]{3}{*}{ Treatment } & \multicolumn{4}{|c|}{$\log _{10}$ CFU per g (fresh weight) grapevine $\operatorname{root}^{\mathrm{y}}$} & \multirow[b]{3}{*}{ Average } \\
\hline & \multicolumn{4}{|c|}{ Months after inoculation } & \\
\hline & 1 & 7 & 14 & 22 & \\
\hline VAR03-1 & $7.24 \pm 0.15$ & $6.91 \pm 0.23$ & $6.18 \pm 0.39$ & $4.67 \pm 0.84$ & $6.25 \pm 0.40$ \\
\hline Nontreatment & $<2^{\mathrm{z}}$ & $<2$ & $<2$ & $<2$ & - \\
\hline
\end{tabular}

y Data are means of three grapevines. Mean $\log _{10} \pm$ standard error

z The approximate detection limit was $10^{2}$ colony forming units (CFU). 
biosis assay was preformed not only on YMA medium but also on Stonier medium by Stonier's method $(34,35)$. Though K84 inhibited indicator strains including tumorigenic $A$. tumefaciens except $\mathrm{C} 054$ and tumorigenic $A$. rhizogenes in the same as on YMA medium, A. vitis VAR03-1 as a test strain and tumorigenic strains as an indicator could not grow and produce a halo of inhibition (data not shown). We have already reported that VAR03-1 produced a type of bacteriocin and inhibited tumorigenic $A$. vitis on YMA medium (16). In this study, we found that VAR03-1 produced a halo of inhibition against not only tumorigenic $A$. vitis but also $A$. tumefaciens and $A$. rhizogenes, clarifying that the bacteriocin produced by VAR03-1 also could inhibit A. tumefaciens and A. rhizogenes. In the biological control test, VAR03-1 actually controlled crown gall of tomato and rose caused by tumorigenic A. tumefaciens and A. rhizogenes, respectively (Table 2 ), indicating the possibility that the bacteriocin of VAR03-1 might be one of the factors in the control of crown gall disease.

However, whether only the bacteriocin production of VAR03-1 is related to the inhibition of tumor formation in planta must be investigated because Burr et al. (7) reported that biological control of grapevine crown gall by nonpathogenic $A$. vitis strain F2/5 was neither associated with agrocin production nor competition for attachment sites on grapevine cells. Though the inhibition halo of VAR03-1 was significantly wider than that of K84 against eight indicator strains $(P<0.05)$ (Table 4$)$, VAR03-1 treatment reduced the percent-

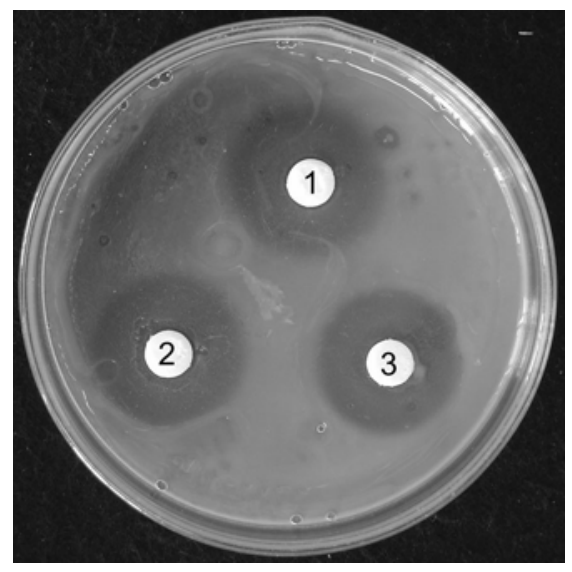

Fig. 3. In vitro antibiosis assay against tumorigenic Agrobacterium vitis strain G-Ag-27 as indicator strain. Paper disk no. 1 to 3 with a suspension of each isolate obtained from grapevine roots 18 months after treatment for $24 \mathrm{~h}$ in a cell suspension $\left(10^{8}\right.$ cells $\left./ \mathrm{ml}\right)$ of VAR03-1 in survival experiment of Table 6 were placed on yeast mannitol agar medium plates, which were then misted with a dilute suspension of G-Ag-27. age of plants with tumors in tomato and rose experiments as well as K84 treatment (Table 2), indicating that the width of the inhibition halo was not involved in the degree of the inhibitory effect of strains VAR03-1 and K84, respectively. We plan to generate a mutant strain of VAR03-1 that lacks bacteriocin by transposon mutagenesis, and we will then investigate whether the bacteriocin-minus mutant inhibit tumors formation to reveal the main factor of VAR03-1 to control crown gall disease.

K84 did not inhibit growth of tumorigenic A. tumefaciens strain $\mathrm{C} 054$ in this antibiosis assay (Table 4) but did control crown gall of tomato caused by a mixture of tumorigenic strains containing C054 (Table 2). Kerr (14) reported that the biological control of $\mathrm{K} 84$ depended on production of agrocin 84 , but Makino (23) found that K84 could control crown gall of rose caused by tumorigenic A. rhizogenes strain R73, which was insensitive to agrocin 84 , indicating that the control activity of K84 depends on factors besides agrocin 84 . K84 may compete for nutrients or attachment sites on plant cells against other agrobacteria in the rhizosphere. Our result that K84 inhibited tumor formation caused by tumorigenic strains, including C054 in planta, supports Makino's report (23), though there is a possibility that the effect of biological control was achieved by the antibiotic activity against agrocin-sensitive strains $\mathrm{CH} 3$ and $\mathrm{CH} 5$, which were the majority in the cell suspension mixture. Whether VAR03-1 has a competitive action like K84 is a very interesting question; thus, study of the control mechanism of VAR03-1 should be continued.

Some opines can be catabolized by the inciting bacteria by using functions encoded by the Ti-plasmid, and K84 is effective against only the nopaline/agrocinopine A strains of agrobacteria (12). Tumorigenic A vitis vitopine strains are broadly distributed in Japan, and strain G-Ag-27 induces vitopine (29). Thus, it was verified that VAR03-1 was effective against at least the vitopine strain (Fig. 1; Tables 2, 3, and 4). What kinds of opine-type strains VAR03-1 is applicable against should be investigated in the future.

As far as we know, there is no effective antagonist to control crown gall of not only grapevine caused by tumorigenic A. vitis but also in the other plants caused by Agrobacterium spp. anywhere in the world. This study is the first report that one nonpathogenic strain, VAR03-1, can effectively reduce tumor formation of crown gall in grapevine, rose, and tomato due to tumorigenic $A$. vitis, $A$. rhizogenes, and $A$. tumefaciens. Furthermore, in the field tests, strain VAR03-1 similarly controlled crown gall of grapevine. Strain VAR03-1 is a promising agent for the control of crown gall of not only of grapevine but also of other plants, and the applicability of VAR03-1 for many kind of plants in the field should be further investigated.

TABLE 6. Root colonization of nonpathogenic Agrobacterium vitis strain VAR03-1 and A. rhizogenes strain K84 in the roots of grapevine cv. Neo Muscat after inoculation

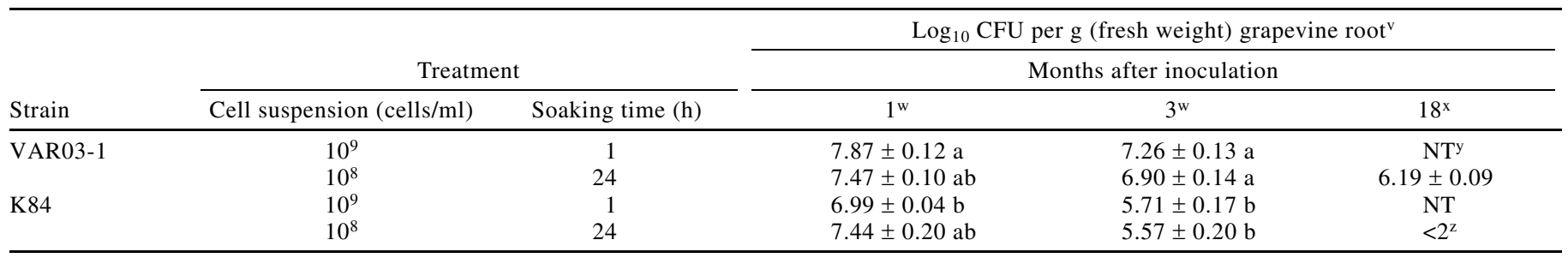

${ }^{v}$ Data are means of 10 grapevines. Mean $\log _{10} \pm$ standard error.

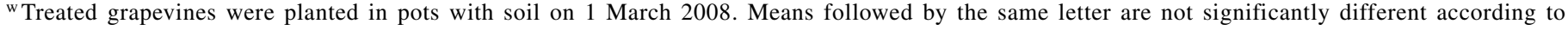
Scheffe's test at $P<0.05$.

${ }^{x}$ Treated grapevines were planted in pots with soil on 6 June 2006 .

y NT; not tested.

z The approximate detection limit was $10^{2}$ colony forming units (CFU). 


\section{LITERATURE CITED}

1. Bouzar, H., Chilton, W. S., Nesme, X., Dessaux, Y., Vaudequin, V., Petit, A., Jones, J. B., and Hodge, N. C. 1995. A new Agrobacterium strain isolated from aerial tumors on Ficus benjamina L. Appl. Environ. Microbiol. 61:65-73.

2. Brisbane, P. G., and Kerr, A. 1983. Selective media for three biovars of Agrobacterium. J. Appl. Bacteriol. 54:425-431.

3. Burr, T. J., Bazzi, C., Süle, S., and Otten, L. 1998. Crown gall of grape: Biology of Agrobacterium vitis and the development of disease control strategies. Plant Dis. 82:1288-1297.

4. Burr, T. J., and Katz, B. H. 1983. Isolation of Agrobacterium tumefaciens biovar 3 from grapevine galls and sap, and from vineyard soil. Phytopathology 73:163-165.

5. Burr, T. J., and Otten, L. 1999. Crown gall of grape: Biology and disease management. Annu. Rev. Phytopathol. 37:53-80.

6. Burr, T. J., and Reid, C. L. 1993. Biological control of grape crown gall with nontumorigenic Agrobacterium vitis F2/5. Am. J. Enol. Viticult. 45:213-219.

7. Burr, T. J., Reid, C. L., Taglicti, E., Bazzi, C., and Süle, S. 1997. Biological control of grape crown gall by strain F2/5 is not associated with agrocin production or competition for attachment site on grape cells. Phytopathology 87:706-711.

8. Chen, X. Y., and Xiang, W. N. 1986. A strain of Agrobacterium radiobacter inhibits growth and gall formation by biotype III strains of Agrobacterium tumefaciens from grapevine. Acta. Microbiol. Sin. 26:193-199.

9. Cooksey, D. A., Moore, L. W. 1980. Biological control of crown gall with fungal and bacterial antagonists. Phytopathology 70:506-509.

10. Du Plessis, H. J., Hattingh, M. J., and Van Vuuren, H. J. J. 1985. Biological control of crown gall in South Africa by Agrobacterium radiobacter strain K84. Plant Dis. 69:302-305.

11. Farrand, S. K., van Berkum, P. B., and Oger, P. 2003. Agrobacterium is a definable genus of the family Rhizobiaceae. Int. J. Syst. Evol. Microbiol. 53:1681-1687.

12. Hayman, G. T., and Farrand, S. K. 1988. Characterization and mapping of the agrocinopine-agrocin 84 locus on the nopaline $\mathrm{Ti}$ plasmid pTiC58. J. Bacteriol. 170:1759-1767.

13. Jones, D. A., Kerr, A. 1989. Agrobacterium radiobacter Strain K1026, a genetically engineered derivative of strain K84, for biological control of crown gall. Plant Dis. 73:15-18.

14. Kerr, A. 1980. Biological control of crown gall through production of agrocin 84. Plant Dis. 64:25-30.

15. Kerr, A., and Htay, K. 1974. Biological control of crown gall through bacteriocin production. Physiol. Plant Pathol. 4:37-44

16. Kawaguchi, A., Inoue, K., and Nasu, H. 2005. Inhibition of crown gall formation by Agrobacterium radiobacter biovar 3 strains isolated from grapevine. J. Gen. Plant Pathol. 71:422-430.

17. Kawaguchi, A., Inoue, K., and Nasu, H. 2007. Biological control of grapevine crown gall by nonpathogenic Agrobacterium vitis strain VAR03-1. J. Gen. Plant Pathol. 73:133-138.

18. Kawaguchi, A., Sawada, H., and Ichinose, Y. 2008. Phylogenetic and serological analyses reveal genetic diversity of Agrobacterium vitis strains in Japan. Plant Pathol. 57:747-753.

19. Kawaguchi, A., Sawada, H., Inoue, K., and Nasu, H. 2005. Multiplex PCR for the identification of Agrobacterium biovar 3 strains. J. Gen. Plant Pathol. 71:54-59.

20. Kersters, K., and De Ley, J. 1984. Genus III. Agrobacterium Conn 1942. Pages 244-254 in: Bergey's Manual of Systematic Bacteriology, vol. 1. N. R. Kring and J. G. Holt, eds. Williams \& Wilkins Co., Baltimore, MA.

21. López-López, M. J., Vicedo, B., Orellana, N., Piquer, J., and López, M. M. 1998. Behavior of a virulent strain derived from Agrobacterium radiobacter strain $\mathrm{K} 84$ after spontaneous Ti plasmid acquisition. Phytopathology 89:286-292.
22. Makino, T. 1986. Biological control of crown gall by Agrobacterium radiobacter strain K84. Shokubutsu Boeki. Plant Prot. 40:540-546 (in Japanese).

23. Makino, T. 1993. Studies on biological control of crown gall of rose, chrysanthemum and Photinia glabra, hairy root of muskmelon, and gummy stem blight of muskmelon. Tech. Bull. Shizuoka Agric. Exp. Stn. 17:1-100.

24. Moore, L. W., and Warren, G. 1979. Agrobacterium radiobacter strain 84 and biological control of crown gall. Annu. Rev. Phytopathol. 17:163-179.

25. Ophel, K., and Kerr, A. 1990. Agrobacterium vitis sp. nov. for strains of Agrobacterium biovar 3 from grapevines. Int. J. Syst. Bacteriol. 40:236-241.

26. Penyalver, R., and López, M. M. 1999. Cocolonization of the Rhizosphere by pathogenic Agrobacterium strains and nonpathogenic strains K84 and K1026, used for crown gall biocontrol. Appl. Environ. Microbiol. 65:1936-1940.

27. Penyalver, R., Vicedo, B., and López, M. M. 2000. Use of the genetically engineered Agrobacterium strain K1026 for biological control of crown gall. Eur. J. Plant Pathol. 10:801-810.

28. Reader, J. S., Ordoukhanian, P. T., Kim, J. G., de Crécy-Lagard, V., Hwang, I., Farrand, S., and Schimmel, P. 2005. Major biocontrol of plant tumors targets tRNA synthetase. Science 309:1533.

29. Sawada, H. 1994. Studies on differentiation and taxonomy of the genus Agrobacterium. Bull. Fruit Tree Res. Stn. Extra 5:1-110.

30. Sawada, H., Ieki, H., Oyaizu, H., and Matsumoto, S. 1993. Proposal for rejection of Agrobacterium tumefaciens and for revised descriptions for the genus Agrobacterium and for Agrobacterium radiobacter and Agrobacterium rhizogenes. Int. J. Syst. Bacteriol. 43:694702 .

31. Sawada, H., Ieki, H., and Takikawa, Y. 1990. Identification of grapevine crown gall bacteria isolated in Japan. Ann. Phytopathol. Soc. Japan 56:199-206.

32. Staphorst, J. L., van Zyl, F. G. H., Strijdom, B. W., Groenewold, Z. E. 1985. Agrocin-producing pathogenic and nonpathogenic biotype-3 strains of Agrobacterium tumefaciens active against biotype-3 pathogens. Curr. Microbiol. 12:45-52.

33. Stockwell, V. O., Moore, L. W., and Loper, J. E. 1993. Fate of Agrobacterium radiobacter $\mathrm{K} 84$ in the environment. Appl. Environ. Microbiol. 59:2112-2120.

34. Stonier, T. 1956. Labeling crown gall bacteria with $\mathrm{P}^{32}$ for radioautography. J. Bacteriol. 72:259-268.

35. Stonier, T. 1960. Agrobacterium tumefaciens Conn. II. Production of an antibiotic substance. J. Bacteriol. 79:889-898.

36. Wang, H. M., Wang, H. X., Ng, T. B., and Li, J. Y. 2003. Purification and characterization of an antibacterial compound produced by Agrobacterium vitis strain E26 with activity against A. tumefaciens. Plant Pathol. 52:134-139.

37. Webster, J., and Thomson, J. A. 1986. Agrocin-producing Agrobacterium tumefaciens strain active against grapevine isolates. Appl. Environ. Microbiol. 52:217-219.

38. Weller, S. A., and O'Neill, T. M. 2006. Crown gall in organically grown UK tomato caused by tumorigenic strains of Agrobacterium radiobacter. Plant Pathol. 55:571.

39. Young, J. M., Kuykendall, L. D., Martínez-Romero, E., Kerr, A., and Sawada, H. 2001. A revision of Rhizobium Frank 1889, with an emended description of the genus, and the inclusion of all species of Agrobacterium Conn 1942 and Allorhizobium undicola de Lajudie et al. 1998 as new combinations: Rhizobium radiobacter, $R$. rhizogenes, $R$. rubi, R. undicola and R. vitis. Int. J Syst. Evol. Microbiol. 51:89103.

40. Young, J. M., Kerr, A., and Sawada, H. 2005. Genus II. Agrobacterium. Pages 340-345 in: Bergey's Manual of Systematic Bacteriology, 2nd ed. vol. 2. G. M. Garrity, ed. Springer Verlag, New York. 